DOI: $10.31471 / 2311-1399-2019-2(12)-64-70$

\title{
Study of the effect of synthesized high voltage electric charge of a powder mixture on the physical and mechanical properties of epoxy composites for the transport industry
}

\author{
${ }^{1}$ A.V. Buketov*, ${ }^{2}$ O.M. Syzonenko, ${ }^{1}$ O.M. Bezbakh, ${ }^{2}$ A.S. Torpakov, ${ }^{2}$ Ye.V. Lypian \\ ${ }^{1}$ Kherson State Maritime Academy; \\ 20 Ushakov Prospect, Kherson, 73000, Ukraine \\ ${ }^{2}$ Institute of Impulse Processes and Technologies of NAS of Ukraine, Mykolaiv; \\ 43a, Bohoyavlensky (Zhovtnevy) Avenue, Mykolayiv, 54018, Ukraine
}

Received: 18.11.2019 Accepted: 23.11.2019

\begin{abstract}
For the formation of composite materials and protective coatings for the transport industry, ED-20 epoxy dyanoic oligomer, the polyethylene polyamine PEPA and microfine fractions of high-voltage synthesized powder charge were used. The dependence of the content of microdispersed powder on the adhesive, physical and mechanical properties, and residual stresses of epoxy composites has been investigated. It has been proved that for the formation of a composite material or protective coating with improved adhesive and cohesive properties, the optimal particle content is $0.05-0.50$ parts by weight per 100 parts by weight of the ED-20 epoxy oligomer. Such materials are characterized by increased mechanical strength and the ability to resist static and dynamic loads, since their properties are significantly increased compared with the matrix. The obtained results of experimental studies of physical and mechanical properties of composite materials are consistent with the test results of samples with adhesive characteristics, indicating their reliability.
\end{abstract}

Keywords: destructive bending stresses, elastic modulus, epoxy composite, impact strength.

\section{Problem setting}

It is well known $[1,2]$ that today an important problem is to increase the anticorrosion properties of technological equipment parts of various industries. This is especially true for pipelines in the oil and gas transportation industry. They are exposed to intense atmospheric corrosion on the one hand, as well as selective corrosion processes on the other. The latter is especially dangerous, since in the case of intergranular corrosion of metals or alloys, fracture occurs in the areas between the crystals, the expanding crack penetrates into the depth of the material. As a result, the mechanical strength of the detail's area is significantly reduced, which leads to its rapid destruction. In addition, transcrystalline corrosion is no less dangerous when destruction occurs along crystallite grains. In this case, corrosion cracking is caused by the simultaneous action of a corrosive medium and external or internal tensile stresses. This is accompanied by the formation of inter- and transcrystalline cracks and leads to the formation of significant residual stresses and, as a consequence, premature aging and destruction of materials.

* Corresponding author:

ksma@ksma.ks.ua

(C) 2019, Ivano-Frankivsk National Technical University of Oil and Gas.

All rights reserved.
Analysis of recent research and publications

The authors $[1,2]$ have showed that it is possible to increase the reliability of vehicles by using polymer composite materials (CM) and protective coatings based on them. In this regard, the use of epoxy materials, which are characterized by increased anti-corrosion characteristics, is relevant. At the same time, when using epoxy protective coatings, there are important their increased indices of adhesive, physical and mechanical properties. The latter are improved due to the introduction of microdispersed powders into the epoxy oligomer that are active in interfacial interaction. In this regard, it is relevant to use synthesized (including high-voltage electric spark discharge) powders with a small spread in particle shape and dispersion. With this in mind, it is important to conduct a study to determine the critical content of powdered microdispersed charges synthesized by high-voltage electric discharge in the formation of protective epoxy coatings to ensure the reliability of vehicles.

The purpose of the work is to investigate the effect of the powder mixture content synthesized by highvoltage electric discharge on the adhesive, physical and mechanical properties of epoxy composites for the transport industry.

\section{Materials and research methods}

As the main component for the binder during the formation of epoxy CMs there is chosen ED-20 epoxy oligomer (GOST 10587-84), which is characterized by high adhesive and cohesive strength, slight shrinkage 
Table 1 - The results of HVED synthesis of the filler

\begin{tabular}{|c|c|c|c|c|c|}
\hline \multirow{2}{*}{ The initial composition } & \multirow{2}{*}{ Composition after processing } & \multirow{2}{*}{$\begin{array}{c}\text { Electrode } \\
\text { system }\end{array}$} & \multicolumn{3}{|c|}{ Diameter after processing $d, \mu \mathrm{m}$} \\
\cline { 4 - 6 } & & 1 & $d_{\min }$ & $d_{\max }$ & $D_{a v}$ \\
\hline $\mathrm{Fe}(75 \%)+\mathrm{Ti}(25 \%)$ & $\begin{array}{c}\mathrm{Fe}(70 \%)+\mathrm{Ti}(10 \%)+ \\
+\mathrm{TiC}(15 \%)+\mathrm{Fe}_{3} \mathrm{C}(5 \%)\end{array}$ & 1 & $\sim 1$ & 112 & 11,5 \\
\hline
\end{tabular}
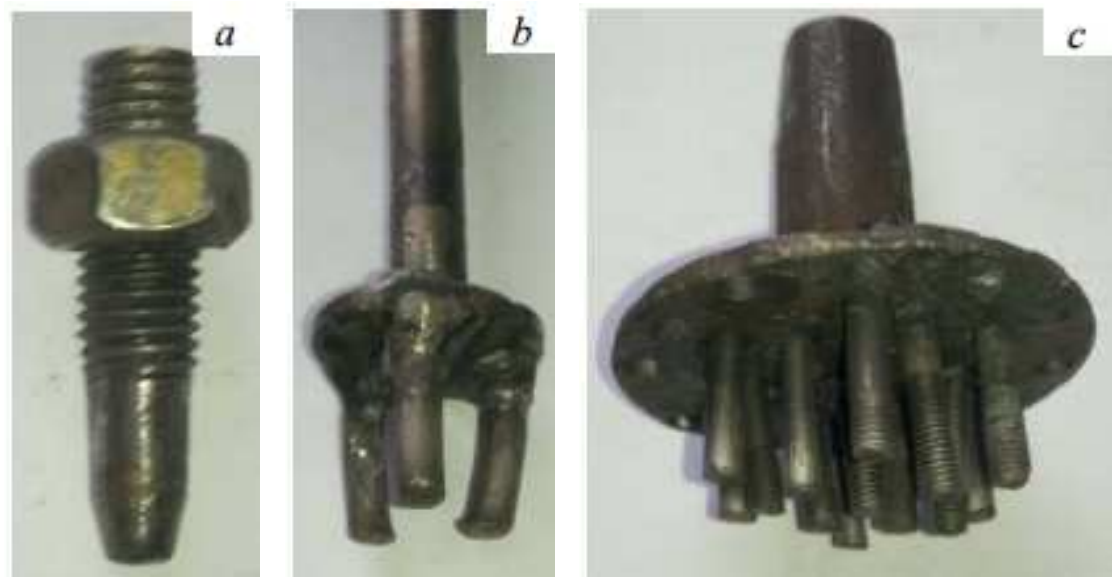

a) 1-point, b) 3-point, c) 15-point

Figure 1 - The design of electrode systems

and manufacturability when applying on a complex profile surface.

For the crosslinking of epoxy compositions, there is used the polyethylene polyamine (PEPA) (TU 6-05241-202-78), which allows the materials to harden at room temperatures. PEPA is a low molecular weight substance that consists of the following interrelated components: $\left[-\mathrm{CH}_{2}-\mathrm{CH}_{2}-\mathrm{NH}-\right]_{\mathrm{n}}$. The $\mathrm{CM}$ is crosslinked by introducing a hardener into the composition at a stoichiometric ratio of components with a content (parts by weight) of ED-20: PEPA - $100: 10$.

A synthesized powder mixture (SPM) was used as a microdispersed filler for experimental studies. The filler was formed by high voltage electric discharge (HVED) synthesis. For a high voltage electric discharge synthesis of a filler, there was used a research stand, described in detail in [3]. A mixture of powders of the following initial composition was used as the starting material: $\mathrm{Fe}(75 \%)+\mathrm{Ti}(25 \%)$. In the study, the accumulated energy of a single discharge $\left(W_{l}\right)$ was $1 \mathrm{~kJ}$, and the integral specific energy of the discharge $\left(\mathrm{W}_{\text {spec }}\right)$ was $25 \mathrm{MJ} / \mathrm{kg}$.

In the process of researches, we varied the distribution of the electric field and plasma formations in the volume of the discharge chamber by using various types of electrode systems (see Table 1 and Fig. 1) [3-5]. In this work, we used a 1-point design of the electronic system.

The use of various electrode systems made it possible to control the distribution of the influence intensity of the main HVED factors [2, 3]. So, if in the case of using a 1-point system, most of the accumulated energy is transformed into shock waves, then the use of 15-point systems can increase the intensity of the influence of thermal and current factors.

The research results show that as a result of the HVED treatment, all processed particles are ground and their phase composition is changed with the synthesis of high-modulus $\mathrm{TiC}$ and $\mathrm{Fe}_{3} \mathrm{C}$ compounds (see Table 1).

Epoxy composites were formed by the following technology: heating the resin to a temperature of $T=353 \pm 2 \mathrm{~K}$ and holding at this temperature for a time $\tau=20 \pm 0.1 \mathrm{~min}$; hydrodynamic combination of oligomers and filler particles over time $\tau=10 \pm 0.1 \mathrm{~min}$; ultrasonic treatment (UST) of the composition over time $\tau=1.5 \pm 0.1 \mathrm{~min}$; cooling the composition to room temperature over time $\tau=60 \pm 5 \mathrm{~min}$; introducing a hardener and mixing the composition for a time $\tau=5 \pm 0.1 \mathrm{~min}$. The CM was hardened under the regime as follows: the formation of samples and their exposure for a time $\tau=12.0 \pm 0.1 \mathrm{~h}$ at a temperature of $T=293 \pm 2 \mathrm{~K}$, heating at a rate of $v=3 \mathrm{~K} / \mathrm{min}$ to a temperature of $T=393 \pm 2 \mathrm{~K}$, exposure for a time $\tau=2.0 \pm 0.05 \mathrm{~h}$, slow cooling to a temperature of $T=293 \pm 2 \mathrm{~K}$. In order to stabilize the structural processes in the composite, the samples were held in the air for $\tau=24 \mathrm{~h}$ at a temperature of $T=293 \pm 2 \mathrm{k}$ followed by experimental tests.

The following properties of the $\mathrm{CM}$ were also researched: adhesive strength, residual stresses, destructive stresses, flexural bending modulus and toughness.

The adhesion strength of the CM to a metal base was investigated by measuring the destructive stresses (the "fungus method") with a uniform separation of a pair of stitched samples according to the GOST Standard 14760-69. The study of the adhesive shear strength was carried out according to the GOST Standard 14759-69, similarly, the tensile strength of adhesive joints of samples was measured by UM-5 tensile testing machine at a load speed of $v=10 \mathrm{~m} / \mathrm{s}$. The diameter of the working part of patterns during the pull-off process was $d=25 \mathrm{~mm}$. It should be noted that the stitching area of the studied samples as a result of a shift and shear was the same. 


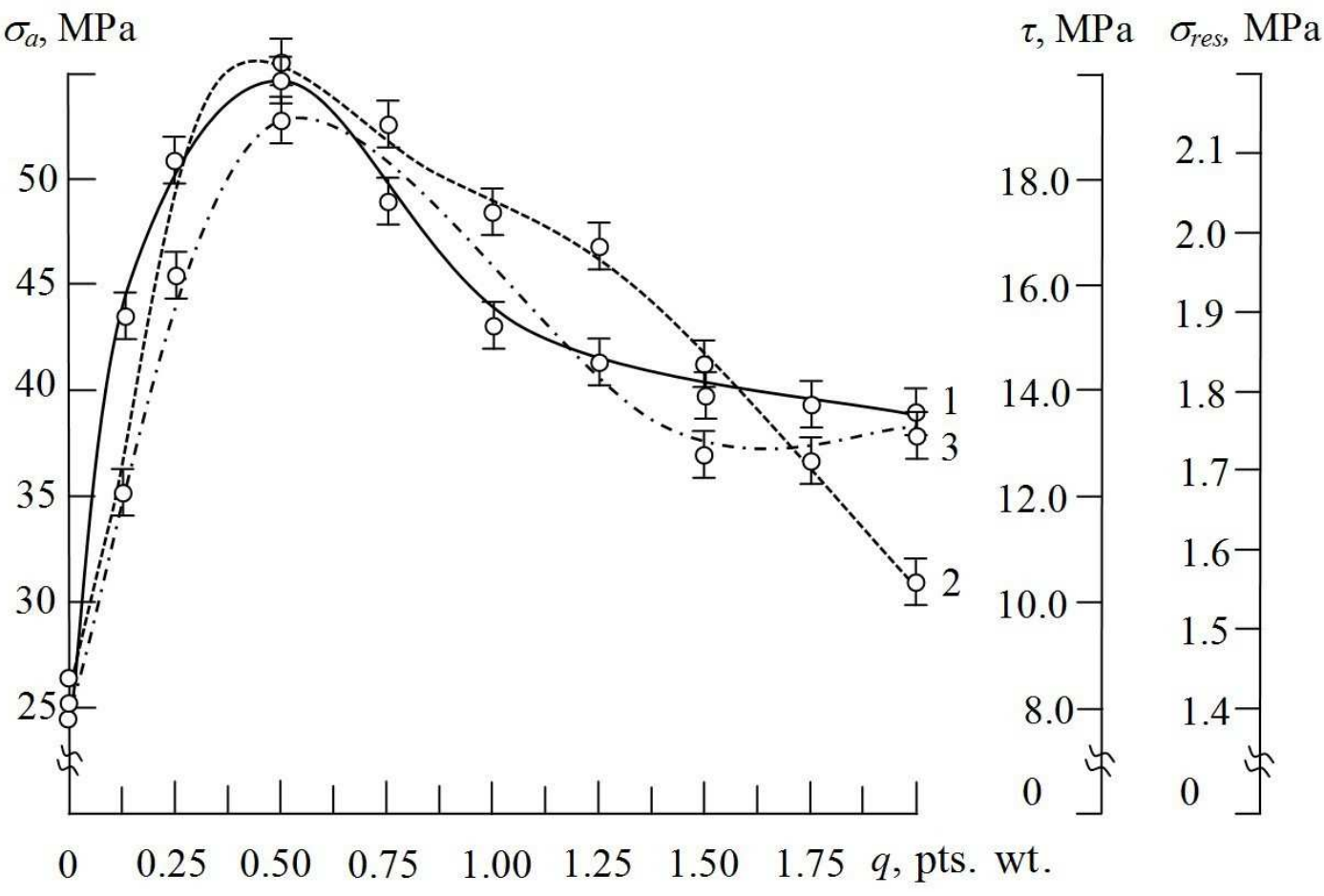

1 - pull-off adhesion $\left(\sigma_{a}\right) ; 2$ - shear adhesion $(\tau)$; 3 - residual stresses $\left(\sigma_{\text {res }}\right)$. The base material is steel St 3

Figure 2 - Dependence of adhesive strength and residual stresses in the CM on the content of SPM

The residual stresses in the coatings were determined using the cantilever method [4]. A coating with a thickness of $\delta=0.3-0.8 \mathrm{~mm}$ was formed on a metal base. Basic parameters were as follows: total length $l=100 \mathrm{~mm}$, working length $l_{0}=80 \mathrm{~mm}$, thickness $\delta=0.3 \mathrm{~mm}$.

Destructive stresses and flexural modulus were determined according to the GOST Standards 4648-71 and 9550-81, respectively. The parts parameters were as follows: the length $l=120 \pm 2 \mathrm{~mm}$, the width $b=15 \pm 0.5 \mathrm{~mm}$ and the height $h=10 \pm 0.5 \mathrm{~mm}$.

The impact strength was determined by the Charpy impact test in accordance with the GOST Standard 4647-80 by means of a MK-30 pendulum head at a temperature of $T=298 \pm 2 \mathrm{~K}$ and relative humidity $d=50 \pm 5 \%$. The parts were used with the following parameters: $(63.5 \times 12.7 \times 12.7) \pm 0.5 \mathrm{~mm}$. The distance between the supports was $40 \pm 0.5 \mathrm{~mm}$.

The values deviation in the study of adhesive, physical and mechanical properties indicators of the CM was $4-6 \%$ of the nominal.

The studies results and their discussion. The properties of the modified and sonicated epoxy matrix were previously experimentally investigated. It was proved (Fig. 2) that the indices of its adhesive strength at rupture and displacement, as well as residual stresses were respectively $\sigma_{a}=24.8 \mathrm{MPa}, \tau=8.5 \mathrm{MPa}$, $\sigma_{3}=1.4 \mathrm{MPa}$. It was also experimentally proved (Fig. 2, curve 1) that the introduction of a synthesized powder mixture (SPM) into the epoxy oligomer in an amount of $q=0.05-0.25$ pts. wt. per 100 pts. wt. of ED-20 provided an increase in the indicators of the adhesion strength at the CM pull-off from $\sigma_{a}=24.8 \mathrm{MPa}$ to $\sigma_{a}=31.3-50.4 \mathrm{MPa}$. The maximum value at the dependence curve "adhesive strength at rupture - the content of the SPM filler" was observed in the presence of the CM additive in the amount of $q=0.50$ pts. wt. In this case, a material with an adhesion strength is formed at the CM pull-off $\sigma_{a}=53.9 \mathrm{MPa}$. Further, the increase in the content of the additive from $q=0.75$ pts. wt. to $q=2.00$ pts. wt. leaded to a deterioration in the adhesive characteristics of the developed CMs, because their adhesive strength monotonically decreased to $\sigma_{a}=39.7$ $\mathrm{MPa}$. It was believed that it was not advisable to increase the amount of filler in epoxy CM, as evidenced by the monotonous nature of the deterioration of properties with increasing amount of an additive.

The results of the study allow us to state the effectiveness of the synthesized high voltage electric discharge of the powder mixture on interfacial interaction during the polymerization of epoxy materials. As shown above, the introduction of particles even at a low content ( $\mathrm{q}=0.05$ pts. wt.) leads to a significant increase in the CMs adhesion strength. In our opinion, this occurs primarily due to the fact that during high voltage electric discharge synthesis of powder in the form of $\mathrm{Fe}$ and $\mathrm{Ti}$ particles as a result of intense stored energy, which is mainly transformed into shock waves, there are additionally formed $\mathrm{Fe}$ and $\mathrm{Ti}$ carbides (Table 1). Such transformations not only increase the strength and hardness of the filler, but also provide surface activity of the additives to interact with the hydroxyl, carbonyl and epoxy groups of the epoxy resin during crosslinking of CMs. In addition, the authors [3-5] have proved that titanium and iron carbides particles are localized on the surface of the particles, and they are mainly the activators of forming physical 
and chemical interphase bonds in the structure formation of materials. It should be noted that there is experimentally determined the critical filler content, which is $\mathrm{q}=0.50$ pts. wt., in the CM. The introduction of additives precisely at this content provides for the maximum transfer of the polymer to the state of the outer surface layers around the filler particles [1, 2], and, accordingly, helps to increase the adhesive strength of the composites.

Additionally, the shear adhesion of the developed composites has been investigated in the work. It is proved (Fig. 2) that the dependences of the pull-off adhesion (curve 1) and shear adhesion (curve 2) on the filler content are symbatically correlated. Similarly to preliminary results, the maximum on the " $\tau-q$ " curve was observed for CMs with a particle content of $q=0.50$ pts. wt. In this case, the adhesive strength of the material increases from $\tau=8.5 \mathrm{MPa}$ (for the epoxy matrix) to $\tau=19.9 \mathrm{MPa}$. Subsequently, an increase in the content of particles in the compositions leads to a deterioration in the shear adhesion of CMs. It should be noted that in case of the critical powder content (at $q=0.50$ pts. wt.), the shear adhesion of the developed material increases by 2.3 times in comparison with the matrix. This indicates that the developed composite and its protective coating can be used quite effectively to improve the operational characteristics of parts that operate not only under static, but also dynamic loads.

In order to confirm the reliability of the obtained results, the residual stresses in the protective coatings were additionally studied. As shown above, they were one of the main criteria for the durability and reliability of protective coatings. The authors $[1,2]$ proved that crosslinked composites with a high content of gel fraction were characterized by increased indices of residual stresses. It was proved (Fig. 2, curve 3 ) that the maximum residual stresses over the entire spectrum of the studied CMs was characterized by a composite with a particle content of $q=0.50$ pts. wt. The residual stresses indices of such a coating increase from $\sigma_{\text {res }}=1.4 \mathrm{MPa}$ (for the epoxy matrix) to $\sigma_{\text {res }}=2.1 \mathrm{MPa}$. It should be noted that this material is also characterized by maximum pull-off and shear adhesion strengths, and this indicates the reliability of the obtained results. Additionally, the surface of the epoxy matrix and developed composite coatings were analyzed by optical microscopy. It was shown (Fig. 3) that the surface of the epoxy matrix coating was characterized by irregularities and the presence of craters. It can be argued about the low reliability of such coatings during their operation. The surface of the coating, which contains filler in the amount of $q=0.05$ pts. wt., is gently sloping with minor microroughness and point inclusions (Fig. 3, c, d, shown by arrows). One can indirectly state an increase in the content of the gel fraction in such a material. For a coating with a filler content of $q=0.50$ pts. wt., there was noted the surface uniformity, craters were practically absent, although dark inclusions were observed, indicating uneven structure in the adhesive volume (Fig. 3, e, f). Of particular note is the type of coating surface with an additive content of $q=2.00$ pts. wt. (Fig. 3, g, h). On the surface of the adhesive, there were discovered air inclusions, the clusters of which had a linear and partially branched shape. It can be argued that such inclusions cause deterioration of both the adhesive and cohesive properties of CMs, since they are their concentrators. For their leveling, additional processing of materials should be carried out when they are stitched, for example by vacuum.

Thus, the optimal content of the synthesized high voltage electric discharge of the powder mixture was established for the formation of an epoxy protective coating with maximum adhesive characteristics and low residual stresses. It was proved that with the introduction of the powder in the amount of $q=0.5$ pts. wt. per 100 pts. wt. of ED-20 epoxy oligomer, a material is formed with the following properties: pull-off adhesion $\sigma_{a}=53.9 \mathrm{MPa}$; shear adhesion $\tau=19.9 \mathrm{MPa}$; residual stress $\sigma_{\text {res }}=2.1 \mathrm{MPa}$. This provides an increase of pulloff adhesion indicators, in comparison with the initial epoxy matrix, in 2.2 times, the shear adhesion - in 2.3 times and residual stresses in 1.5 times.

At the next stage, the physical and mechanical properties of the CM with microdispersed filler SPM were investigated. It was experimentally established that the properties of the ultrasonically treated epoxy matrix under the above formation conditions were as follows: the bending modulus of elasticity $E=2.8 \mathrm{GPa}$, destructive bending stresses $\sigma_{\text {bend }}=48.0 \mathrm{MPa}$, impact strength $W=7.4 \mathrm{~kJ} / \mathrm{m}^{2}$.

It has been proved (Fig. 4, curve 1) that the introduction of microparticles with a content of $q=0.05-0.50$ pts. wt. leads to a significant improvement in properties. At this content of particles, CMs are formed with an elastic modulus of $E=3.5-4.3 \mathrm{GPa}$. Subsequently, an increase in the content of SPM leads to a monotonic decrease in the bending modulus of elasticity of the $\mathrm{CM}$ to $\mathrm{E}=3.2 \mathrm{GPa}$ (for the $\mathrm{CM}$ with SPM in the amount of $q=2.00$ pts. wt.).

On the contrary, the analysis of the dependences " $\sigma_{\text {bend }}-\mathrm{q}$ " and "W $-\mathrm{q}$ " allows us to state the following. A maximum (Fig. 4, curve 2 and 3) was observed for CMs with a particle content of $q=0.05$ pts. wt. In this case, there is formed a material, which has the following properties: destructive bending stresses $\sigma_{\text {bend }}=74.3 \mathrm{MPa}$, impact strength $\mathrm{W}=13.6 \mathrm{~kJ} / \mathrm{m}^{2}$. So, it should be noted that the filler should be added to the epoxy resin in an amount of $q=0.05$ pts. wt. for the formation of composites with improved physical and mechanical properties. The formation of such a material provides 1.3 times increase in the bending modulus of elasticity compared to the initial epoxy matrix, destructive bending stresses by 1.5 times, and the impact strength by 1.8 times.

\section{Conclusions}

The research results established the optimum content of microdispersed filler synthesized by a highvoltage electric discharge of a powder mixture for the formation of an epoxy protective coating with improved adhesive, cohesive characteristics and insignificant residual stresses for the increase of the vehicles reliability. 


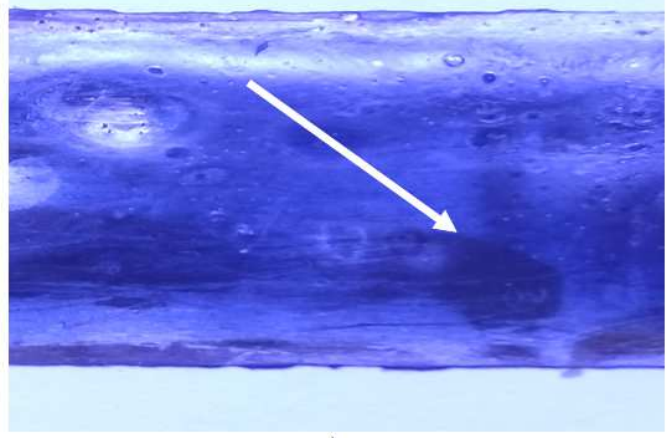

a)

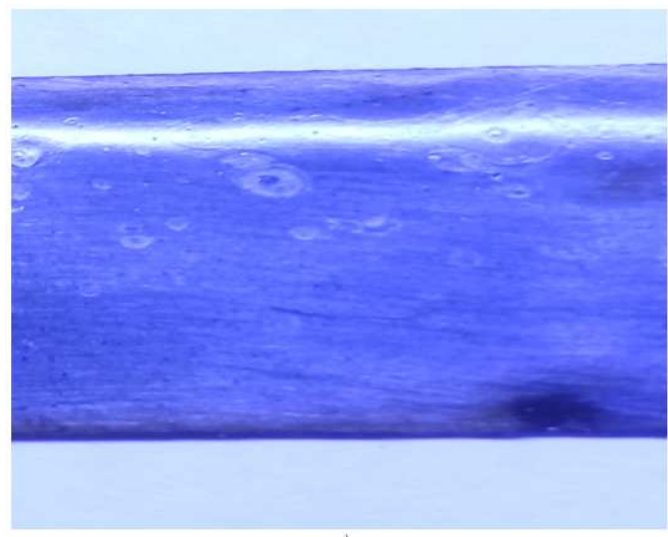

c)

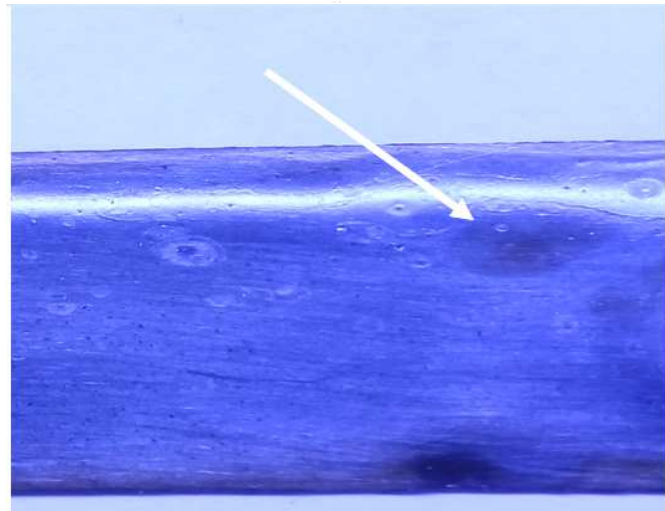

e)

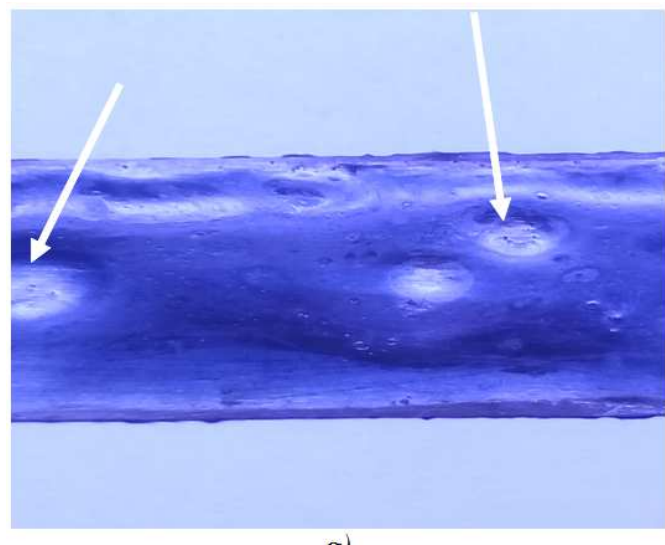

g)

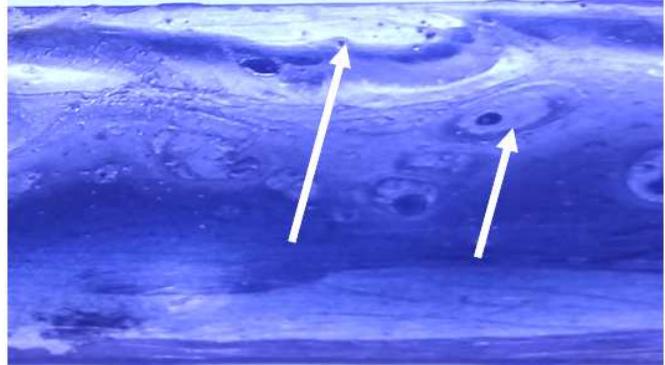

b)

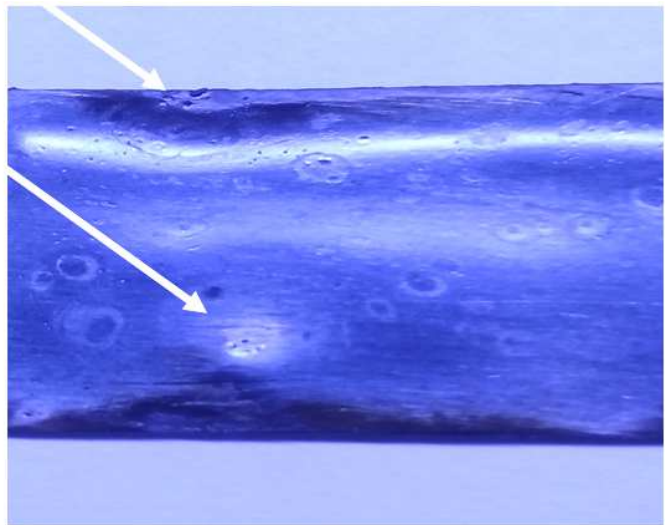

d)

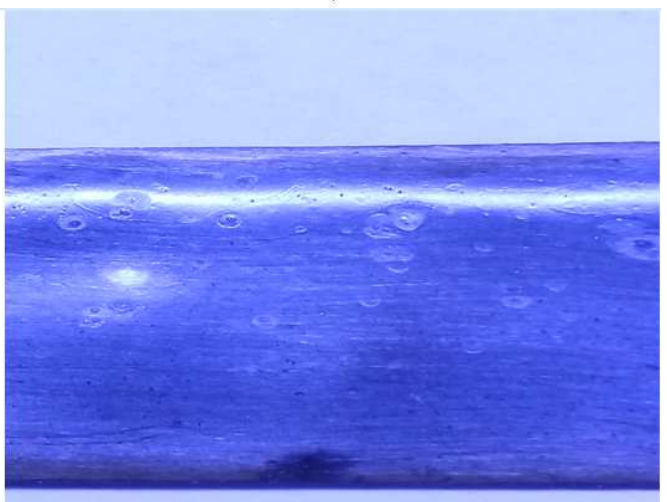

f)

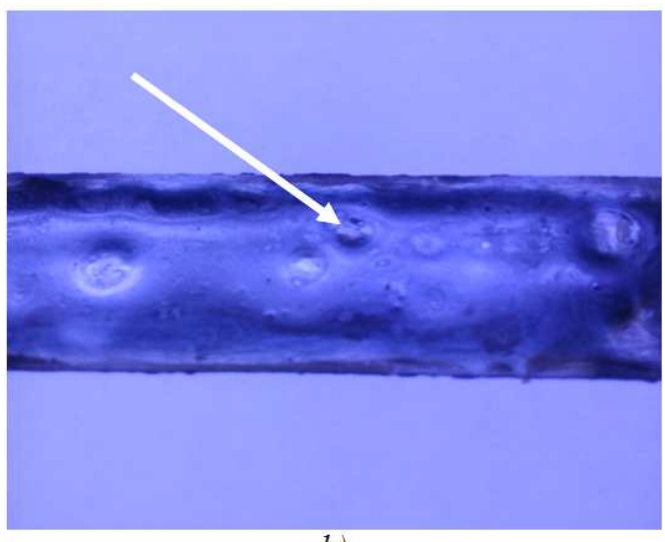

h)

$a, b)$ the original matrix $c, d) 0.05 ; e, f) 0.50 ; g, h) 2.00$ (see designations in the text)

Figure 3 - Microphotographs of the surface of the CM fracture with microadditives, $q$, pts. wt $(1 \times 1)$ 


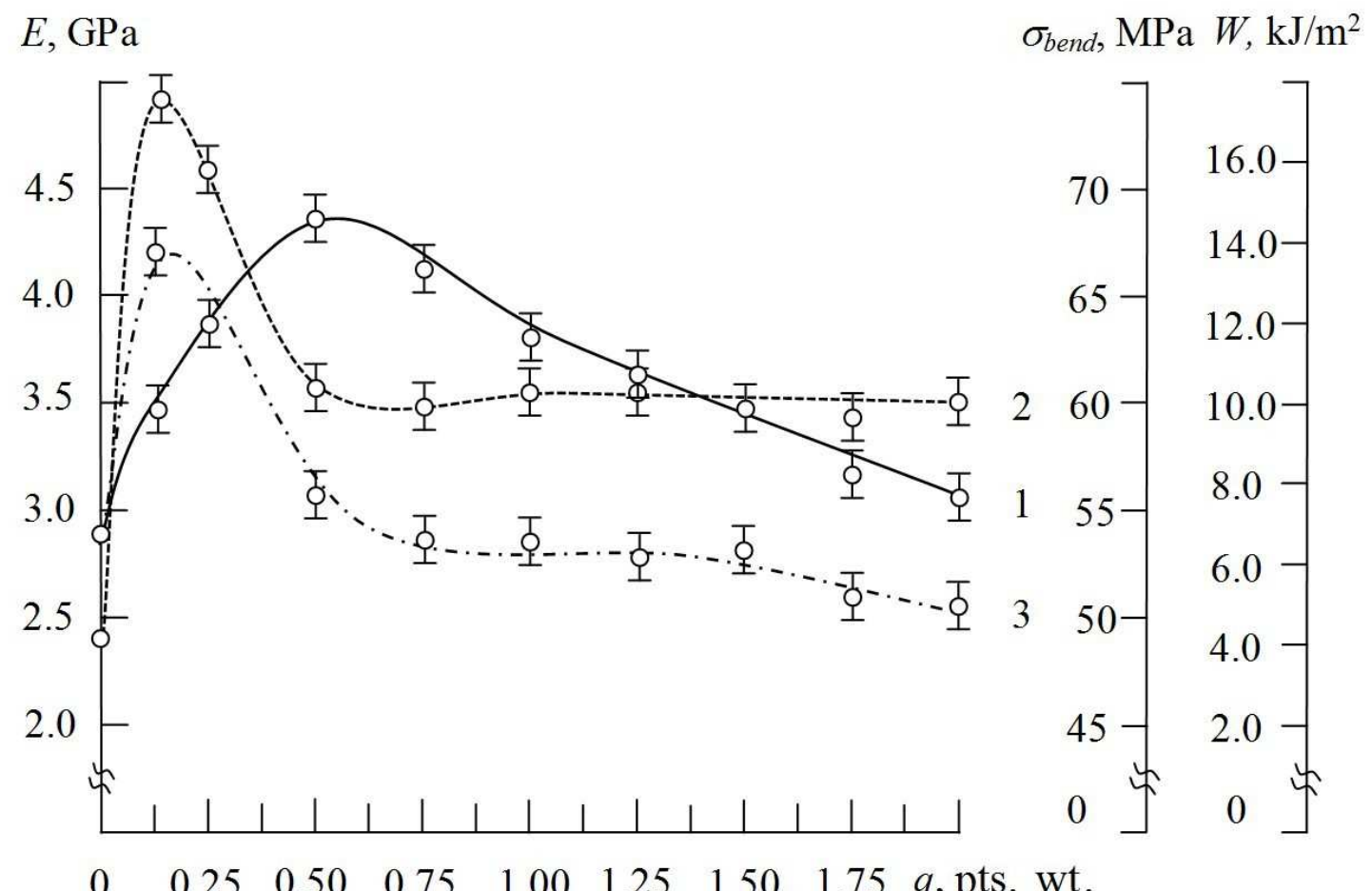

1 - bending modulus of elasticity $(E) ; 2$ - destructive bending stresses $\left(\sigma_{\text {bend }}\right) ; 3$ - impact strength $\left(\mathrm{W}, \mathrm{kJ} / \mathrm{m}^{2}\right)$

Figure 4 - Dependence of the physical, mechanical properties and impact strength of the epoxy matrix on the content of SPM

1. It has proved that with the introduction of the powder in the amount of $q=0.5$ pts. wt. per 100 pts. wt. of ED-20 epoxy oligomer, a material is formed with the following properties: pull-off adhesion $\sigma_{a}=53.9 \mathrm{MPa}$; shear adhesion $\tau=19.9 \mathrm{MPa}$; residual stress $\sigma_{\text {res }}=2.1 \mathrm{MPa}$. This provides an increase of pull-off adhesion indicators, in comparison with the initial epoxy matrix, in 2.2 times, the shear adhesion - in 2.3 times and residual stresses in 1.5 times.

2. It has been found that the introduction of powder mixture particles in an amount of $q=0.05$ pts. wt. per 100 pts. wt. of ED-20 epoxy oligomer provides the formation of a material with the following properties: bending modulus of elasticity $E=3.5 \mathrm{GPa}$, destructive bending stresses $\sigma_{\text {bend }}=74.3 \mathrm{MPa}$, impact strength $W=13.6 \mathrm{~kJ} / \mathrm{m}^{2}$. The formation of such a material provides 1.3 times increase in the bending modulus of elasticity compared to the initial epoxy matrix, destructive bending stresses by 1.5 times, and the impact strength by 1.8 times.

\section{References}

[1] Buketov, AV, Zinchenko, DO \& Smetankin, SO 2017, 'Nanomodified dispersed particles and synthetic fibersfilled epoxy composite materials for the metal-polymer tribosystems of transport vehicles', Nanomechanics Science and Technology: an International Journal, vol. 8, pp. 41-54.

[2] Buketov, A, Maruschak, P, Sapronov, O, Zinchenko, D, Yatsyuk, V \& Panin, S 2016, 'Enhancing performance characteristics of equipment of sea and river transport by using epoxy composites', Transport, vol. 31(3), pp. 333-342.

[3] Syzonenko, O, Baglyuk, G \& Torpakov, A 2012, 'Variation in the particle size of Fe-Ti-B4C powders induced by high-voltage electrical discharge', Powder Metallurgy and Metal Ceramics, vol. 51, iss. 3, pp. 129-136.

[4] Syzonenko, O, Sheregii, E, Prokhorenko, S and others 2017, 'Method of preparation of blend for aluminium matrix', Composites by high voltage electric discharge. Machines. Technologies. Materials, vol. 11, iss. 4, pp. 171173.

[5] Syzonenko, ON, Tregub, VA \& Taftai, IeI 2014, 'Modeling and analysis of electric discharge processes in a Ti powder layer in kerosene', Bulletin of the Ukrainian Material Science Society, iss. 7, pp. 55-61. (in Ukrainian) 
УДК 667.64:678.026

\title{
Дослідження впливу синтезованої високовольтним електророзрядом порошкової шихти на фрізико-механічні властивості епоксидних композитів для транспортної галузі
}

\author{
${ }^{1}$ А. В. Букетов, ${ }^{2}$ О. М. Сизоненко, ${ }^{1}$ О. М. Безбах, ${ }^{2}$ А. С. Торпаков, ${ }^{2}$ С. В. Липян \\ ${ }^{1}$ Херсонська державна морська академія; \\ проспект Ушакова, 20, м. Херсон, 73003, Украӥна \\ ${ }^{2}$ Інститут імпульсних процесів і технологій; \\ проспект Богоявленський, 43а, Миколаӥв, 54018, Украӥна
}

Для формування композитних матеріалів і захисних покриттів для транспортної галузі використано епоксидний діановий олігомер ЕД-20, твердник поліетиленполіамін ПЕПА і мікродисперсні частки синтезованої високовольтним електророзрядом порошкової шихти. Досліджено вплив вмісту мікродисперсного порошку на адгезійні і фізико-механічні властивості та залишкові напруження епоксидних композитів. Доведено, що для формування композитного матеріалу чи захисного покриття 3 поліпшеними адгезійними $\mathrm{i}$ когезійними властивостями оптимальний вміст часток становить 0.05-0.50 мас.ч. на 100 мас.ч. епоксидного олігомеру ЕД-20. Такі матеріали характеризуються підвищеною механічною міцністю та здатністю чинити опір статичним і динамічним навантаженням, оскільки показники їх властивостей суттєво підвищуються порівняно з матрицею. Отримані результати експериментальних досліджень фізико-механічних властивостей композитних матеріалів, добре узгоджуються з результатами випробувань зразків із адгезійними характеристиками, що свідчить про їх достовірність.

Ключові слова: епоксидний композит, модуль пружності, руйнівні напруження на вигин, ударна міциність. 